\title{
Seasonal study of concentration of heavy metals in waters from lower São Francisco River basin, Brazil
}

\author{
A. M. Souza ${ }^{a}$, A. M. Salviano ${ }^{b}$ J. F. B. Melo ${ }^{a}$, W. P. Felix ${ }^{a}$, C. S. Belém ${ }^{a}$ and P. N. Ramos ${ }^{c}$ \\ ${ }^{a}$ Laboratório de Aquicultura e Bioquímica, Universidade Federal do Vale do São Francisco - UNIVASF, \\ Rodovia BR 407, Km 12, Lote 543, Distrito de Irrigação Senador Nilo Coelho, CEP 56300-990, Petrolina, PE, Brazil

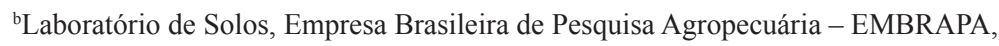 \\ Rodovia BR 428, Km 152, CEP 56302-970, Petrolina, PE, Brazil \\ 'Departamento de Pós-graduação em Gestão de Recursos Humanos nas Organizações, Faculdade de Ciências \\ Aplicadas e Sociais - FACAPE, Campus Universitário, s/n, Vila Eduardo, CEP 56328-903, Petrolina, PE, Brazil \\ *e-mail: anderson_zootecnia@yahoo.com.br
}

Received: March 27, 2015 - Accepted: July 20, 2015 - Distributed: November 30, 2016

(With 1 figure)

\begin{abstract}
In this study we determined the concentration of metals $(\mathrm{Cd}, \mathrm{Cr}, \mathrm{Cu}, \mathrm{Fe}, \mathrm{Mn}, \mathrm{Ni}, \mathrm{Pb}$ and $\mathrm{Zn})$ in the water lower São Francisco River basin, to evaluate the influence of urbanization and industrialization on environmental changes in the water resource. All samples were analyzed using the IUPAC adapted method and processed in an atomic absorption spectrophotometer. The sampling stations located near the industrial areas were influenced by industrialization because they presented higher concentrations of $\mathrm{Cd}, \mathrm{Cr}, \mathrm{Ni}$ and $\mathrm{Cu}$. The other sampled locations showed changes with regard the trace elements probably originating in the soil, like $\mathrm{Fe}, \mathrm{Zn}$ and $\mathrm{Pb}$. There was a gradual increase in the concentrations of metals, in general, in the period of highest rainfall of the hydrographic network. Overall, except for $\mathrm{Zn}$ and $\mathrm{Mn}$, the trace elements exceeded the maximum allowed value established by national legislation (CONAMA). Lower São Francisco River basin has suffered interference from urbanization and industrialization, so awareness programs should be developed so as to control and lessen future problems.
\end{abstract}

Keywords: trace elements, industrialization, São Francisco river, urbanization.

\section{Estudo sazonal das concentrações de metais pesados em águas da bacia do submédio rio São Francisco, Brasil}

\section{Resumo}

Neste trabalho foi determinada a concentração dos metais $(\mathrm{Cd}, \mathrm{Cr}, \mathrm{Cu}, \mathrm{Fe}, \mathrm{Mn}, \mathrm{Ni}, \mathrm{Pb}$ e $\mathrm{Zn}$ ) na água do submédio Rio São Francisco para avaliar a influência da urbanização e da industrialização nas modificações ambientais do recurso hídrico. Todas as amostras foram analisadas usando o método IUPAC adaptado e processados em um espectrofotômetro de absorção atômica. As estações de amostragem localizadas próximas às áreas industriais sofreram influência da industrialização por apresentarem concentrações mais elevadas de $\mathrm{Cd}, \mathrm{Cr}, \mathrm{Ni}$ e $\mathrm{Cu}$. Os demais locais amostrados apresentaram modificações com relação aos elementos traços de provável origem sedimentar como $\mathrm{Fe}, \mathrm{Zn}$ e $\mathrm{Pb}$. Houve aumento gradativo nas concentrações dos metais, de forma geral, no período de maior pluviosidade da rede hidrográfica. Em geral, com exceção do $\mathrm{Zn}$ e Mn, os elementos traços ultrapassaram o valor máximo permitido, estabelecido pela legislação nacional (CONAMA). O submédio Rio São Francisco tem sofrido interferência da urbanização e industrialização, por isso, é preciso que, programas de conscientização sejam estabelecidos, para controlar e amenizar problemas futuros.

Palavras-chave: elementos traços, industrialização, rio São Francisco, urbanização.

\section{Introduction}

The impacts of human activity on aquatic systems have been reported for over 200 years. However, coupled to fast population growth, industrialization, as well as some agricultural activities, increased the risks of pollution in natural environments like water, soil and the atmosphere

in the last 150 years (Santoyo et al., 2000). The problems of contamination with toxic metals started in the Middle Age, with the mining activities, but were accelerated in the beginning of the nineteen century, with the processing of metals in chemical and foundry plants (Vink et al., 1999). 
Heavy metals are toxic elements released by some types of industrial effluents (Tarley and Arruda, 2003). Many metals form stable complexes with biomolecules, and their presence, even at low quantities, can be harmful to plants and animals. The free metal ion is the most toxic form to aquatic life (Florence and Batley, 1980). The bioavailability and toxicity, as well as the dependence of the species upon transport phenomena, are related to the chemical form of the substance. Thus, determining the total concentration of a heavy metal in a water sample provides relative information about its toxicity. Contaminant metals can be controlled through sorption systems (Evans, 1989). Discussions on the metallic uptake in river basins cannot be performed without considering the routes through which metals are removed from the solution, be it by precipitation as insoluble salt and/or by adsorption on the surface of solids (Stumm, 1992).

When present in an aquatic system, heavy metals are a threat to human health due to their impacts on the quality of the water, foods and ecosystems (Ernst, 1996). Metals such as $\mathrm{Cu}, \mathrm{Pb}$ and $\mathrm{Zn}$ are components of household garbage. Based on material-flow studies, a contribution of $50-80 \%$ of these metals may come from urban sewage (Boller, 1997).

The quality of surface waters will depend on the type of waste released by many industrial processes. Tanneries generate a load potentially contaminating formed by $\mathrm{Ca}$, free sulfides, high $\mathrm{pH}$, organic matter, total $\mathrm{Cr}$ has high toxicity, and suspended solids.

Another source of contamination by metals are metallurgical industries (Sell, 1992). For many decades, production of $\mathrm{Pb}, \mathrm{Cu}, \mathrm{Zn}$ and $\mathrm{Fe}$ ranged around 200,000 tons per year in Brazil, so these were classified as dangerous disposals (Hajdú and Licskó, 1999). A variety of aquatic systems has been contaminated by metals generated from the oxidation of mineral sulfite, which is accelerated by the exposure of metal sulfites to air as a result of the mining activity (Paulson, 1997). Adsorption of heavy metals at the surface of the suspended particulate matter and river sediment has been shown as a geochemical process of removal of metals in solution (Stumm and Morgan, 1981).

The great industrial development is one of the main factors responsible for the contamination of our waters, due to both the negligence in treating industrial waste before dumping it in the rivers, and the accidents and increasingly often carelessness, which causes the release of many pollutants in the aquatic environments, contributing for the natural waters to become residuary. Thus, the industrial sector is the mostly diversified source of introduction of heavy metals in the aquatic environment.

The cities of Petrolina-PE and Juazeiro-BA, located in the Brazilian semi-arid region, together, form a metropolis. They are divided by the São Francisco River lower basin portion, and are connected by the Presidente Dutra bridge. Medium-sized cities have together a population of approximately six hundred thousand inhabitants (IBGE, 2013). The presence of several industries close to the São Francisco River, which intersects both cities, raises concern about the uptake of contaminant metals in these waters, which serve the population in many ways. The rampant growth of urban centers is oblivious to the difficulties that arise from the installation of industries. Their implantation, which in earlier times had not yet been studied or had its environmental impacts reported, currently requires supervision over compliance with the contaminants rates established by legislation, even if they are not reasoned as to their applicability and consequences to the environment and living beings.

The main objective of this study is to evaluate the presence and average concentration total of heavy metals in the water of lower São Francisco River basin, in the Petrolina-PE and Juazeiro-BA section, investigating the possible natural sources and influences of anthropogenic activities on the water quality.

\section{Material and Methods}

\subsection{Geographical location}

The area to be studied is located in the West region of the states of Pernambuco and Bahia, Brazil, comprising the municipalities of Petrolina-PE and Juazeiro-BA. These municipalities are on the course of São Franciso River basin, which is responsible for all the water supply to the region. The areas under study are specifically located at strategic points of the river (Figure 1).

Two periods of the hydrological year were sampled: September to December 2013 and January to March 2014, which characterized the collection periods 1 and 2, respectively. There was an average rainfall of $200 \mathrm{~mm}$ and $3 \mathrm{~mm}$ in period 1 and 2 respectively collection (CPTEC, 2013). These periods in previous years occurred in the seasonality of rainfall collection points, these epochs were determined in order to observe its effect on metal concentrations (IBGE, 2013). Collections of the periods exhibited different flow, which were controlled by dam Sobradinho-BA, averaging 1,100.00 and 2,250.00 $\mathrm{m}^{3} / \mathrm{s}$ in periods 1 and 2 respectively (CHESF, 2014).

Three different areas of the river course were sampled: the urban area (UA) $\left(9^{\circ} 24^{\prime} 25^{\prime}\right.$ " South latitude - 40 30' 7" West longitude) located within the central perimeter that divides both cities; and Balneário de Pedrinhas (BP) (9 $9^{\circ} 16^{\prime} 84^{\prime}$ ' South latitude - 40 19' 11" West longitude) and Ilha do Massangano (IM) ( $9^{\circ} 27^{\prime}$ 24" South latitude - 40 35' 49" West longitude), located 30 and $10 \mathrm{Km}$ away from the metropolis, respectively. Water samples from 5 points of each location were collected, shown in Figure 1 the 15 sampling points, adopting the distance of 500 meters for each point, comprising a total water course of $50 \mathrm{Km}$ of studied area.

\subsection{Preparation of the samples}

The water samples were collected using 1L polyethylene bottles attached to an aluminum support. The containers had a pressure valve connected to a string; when the string was pulled, the restrained air would escape, so the water would have access by pressure (Filizola et al., 2006). The sampling was performed in the deep part, at 


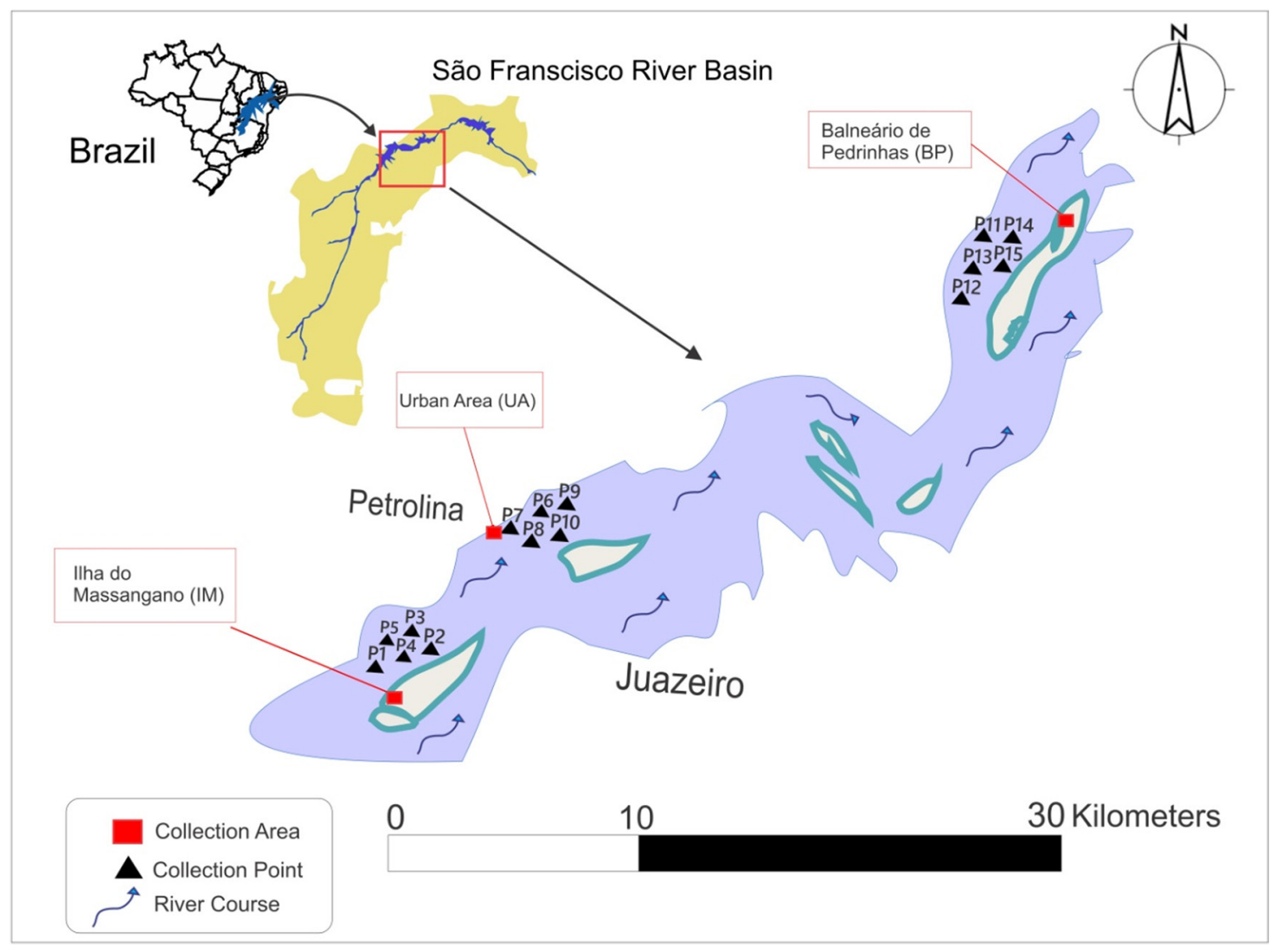

Figure 1. Illustrative map of sampling sites and course of the lower São Francisco River basin.

around $3 \mathrm{~m}$ of depth, at a minimum distance of 50 meters and maximum of 100 meters from the shores (Cachada, 2007), where all collection points were set in these values of depth for the periods collection. The samples were then acidulated with $200 \mu / \mathrm{L}$ concentrated $\mathrm{HNO}_{3}$ P.A. to reach pH 2.0 in a ratio of 1 for $3 \mathrm{~mL}$ and kept refrigerated at $4{ }^{\circ} \mathrm{C}$. Afterwards, the samples were preconcentrated 10 times through convective heating on a hot plate, at approximate temperature of $60^{\circ} \mathrm{C}$, to ensure sufficient metal concentration for the determination, due to the detection limit imposed by the Atomic Absorption Spectrometry technique (Burbure et al., 2006). The analyses were performed in triplicate, the standard deviation (SD) found in the analyzes of traces in triplicate elements.

\subsection{Physicochemical analysis of the water from the river}

During the collections, the physicochemical parameters of the water (temperature, dissolved oxygen, $\mathrm{pH}$, conductivity, ammonia and turbidity) were measured using a Hanna Oxy-Chek portable probe and calorimetric test kits.

\subsection{Instrumentation}

The concentration of metals total was determined using a flame atomic absorption spectrophotometer, AAS. The operating conditions varied for each studied metal (Table 1). The optimal conditions for multi-element determination were established according to recommendations of the manufacturer. The limit of detection (DL) and limit of quantification practicable (PQL) were calculated according to the norms of IUPAC (The International Union of Pure and Applied Chemistry).

\subsection{Chemical reagents and standards}

All the reagents employed in the development of this study were of analytical grade, and the water was highly pure (deionized). The stock solutions were prepared with high purity standards, in $\mathrm{HNO}_{3} 1 \%$ (Merck). Next, the solutions were conditioned in pre-washed polyethylene bottles and decontaminated with $\mathrm{HNO}_{3} 10 \%$ (v/v). A blank was prepared and stored in the same manner.

\subsection{Statistical treatment of the data}

For the analysis of the results obtained, the Resolution no. 357 of CONAMA (Brasil, 2005), of March 17, 2005, was consulted. This resolution addresses the classification of water bodies and environmental guidelines for this nature, as well as establishes the conditions and standards for effluent release, among other measures. Resolution 344 of CONAMA, from March 25, 2004 (Brasil, 2004) was also consulted; this resolution establishes general guidelines and minimum procedures for the evaluation of the material to be dredged in Brazilian waters, and other measures. 
The statistical tests were conducted using the Assistat-7.5 statistical software (Silva, 2010). Data were compared between the different sites of samples. Correlations between the analyzed parameters were made by applying Spearman's test. The probability of 0.05 or less was considered significant.

\section{Results}

The water physicochemical parameters are described in Table 2. They were within the levels established by Resolution no. 357/2005 of CONAMA (Brasil, 2005).

Tables 3 and 4 show the concentration range of the metals evaluated in the lower São Francisco River basin, in the Petrolina-PE and Juazeiro-BA section in the two times of the hydrological year, as well as the standard deviation, maximum value and coefficient of variation of the determinations. It also summarized the maximum allowed value (MAV) established in Resolution no. 357/2005 of CONAMA (Brasil, 2005).

The sampling areas named UA, whose urban and industrial activities are highly intense, presented higher concentrations of metals $\mathrm{Ni}, \mathrm{Cd}, \mathrm{Pb}, \mathrm{Fe}, \mathrm{Cr}$ and $\mathrm{Cu}$ (Table 3 and 4). There was also increase in the concentration of the other metals studied in these locations. At IM, however, there was increase in the average concentration of metals $\mathrm{Ni}$,
$\mathrm{Cd}, \mathrm{Pb}$ and $\mathrm{Fe}$, whose values were far above the allowed. Ilha do Massangano (IM) is characterized by having an area of approximately 250 hectares, centered at the middle of the river. People who live there depend on fishing and subsistence farming. The elevation in the level of these metals might have been caused by the chemicals utilized in these plantations, which are usually disposed without previous treatment directly in the river.

In Table 5 is illustrated the mean values of the correlations of trace elements of all periods and collection points. Highlighting chromium, due to its higher correlation with other trace elements.

\section{Discussion}

The analysis showed that there was no significant statistical difference for $\mathrm{Cd}, \mathrm{Zn}, \mathrm{Pb}, \mathrm{Fe}$ and $\mathrm{Cu}$ in collection Period 1 in the different locations (Table 3). The mean concentrations of $\mathrm{Ni}, \mathrm{Mn}$ and $\mathrm{Cr}$, however, presented statistically significant differences $(p<0.05)$, and the mean contents of $\mathrm{Zn}, \mathrm{Pb}$ and $\mathrm{Cr}$ were higher in Period 1, and the concentrations of $\mathrm{Ni}, \mathrm{Cd}, \mathrm{Fe}, \mathrm{Mn}$ and $\mathrm{Cu}$ were higher in Period 2. Yet, the elements $\mathrm{Cd}, \mathrm{Zn}$ and $\mathrm{Mn}$ differed statistically $(p<0.05)$ in the same period, attributing the occasionally of leaching to the rainfall during collection

Table 1. Operating conditions of the atomic absorption spectrophotometer, detection limits and parameters of the calibration curve for each element.

\begin{tabular}{|c|c|c|c|c|c|c|c|c|}
\hline Element & $\begin{array}{c}\mathbf{W L}^{1} \\
/(\mathbf{n m})\end{array}$ & $\begin{array}{c}\text { Gas flow } \\
/\left(\mathrm{L} \text { min }^{-1}\right)\end{array}$ & Gas type & $\begin{array}{c}\mathbf{D L}^{2} \\
/\left(\mathrm{mg} \mathrm{L}^{-1}\right)\end{array}$ & 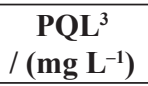 & $\mathbf{X}$ & $\mathbf{Y}$ & $\mathbf{r}^{2}$ \\
\hline $\mathrm{Ni}$ & 233.0 & 2.3 & Air- $\mathrm{C}_{2} \mathrm{H}_{2}$ & 0.0016 & 0.0786 & 0.030 & 0.003 & 0.9945 \\
\hline $\mathrm{Cd}$ & 227.2 & 1.8 & Air- $\mathrm{C}_{2} \mathrm{H}_{2}$ & 0.0017 & 0.0849 & 0.389 & -0.015 & 0.9949 \\
\hline $\mathrm{Zn}$ & 214.9 & 2.0 & Air- $\mathrm{C}_{2} \mathrm{H}_{2}$ & 0.0114 & 0.5725 & 0.038 & 0.023 & 0.9998 \\
\hline $\mathrm{Pb}$ & 218.0 & 2.1 & Air- $\mathrm{C}_{2} \mathrm{H}_{2}$ & 0.0001 & 0.0069 & 0.017 & -0.010 & 0.9994 \\
\hline $\mathrm{Fe}$ & 249.3 & 2.3 & Air- $\mathrm{C}_{2} \mathrm{H}_{2}$ & 0.0058 & 1.2919 & 0.082 & 0.008 & 0.9959 \\
\hline $\mathrm{Mn}$ & 278.5 & 1.9 & Air- $\mathrm{C}_{2} \mathrm{H}_{2}$ & 0.0015 & 0.0773 & 0.172 & 0.012 & 0.9979 \\
\hline $\mathrm{Cr}$ & 356.9 & 2.9 & Air-Ar ${ }^{4}$ & 0.0220 & 1.1023 & 0.018 & 0.006 & 0.9992 \\
\hline $\mathrm{Cu}$ & 323.7 & 1.7 & Air- $\mathrm{C}_{2} \mathrm{H}_{2}$ & 0.0002 & 0.0098 & 0.037 & 0.050 & 0.9994 \\
\hline
\end{tabular}

1- WL: wavelength; 2- DL: detection limit; (DL = $3 \mathrm{RSD} / \alpha$ ), RSD (relative standard desviation) for 10 measures of the analytic white solution and $\alpha$ is angular coefficient of the calibration curve; 3- PQL: Practical quantitation limit. $(\mathrm{PQL}=\mathrm{DL} / \mathrm{DF}), \mathrm{DF}$ (Factor de dilution); 4-Ar: Argon.

Table 2. Means of the physicochemical parameters of the water from lower São Francisco River basin, in Petrolina-PE and Juazeiro-BA section.

\begin{tabular}{|c|c|c|c|c|c|c|}
\hline \multirow{2}{*}{ Parameters } & \multicolumn{2}{|c|}{$\mathbf{U A}^{1}$} & \multicolumn{2}{|c|}{ IM $^{2}$} & \multicolumn{2}{|c|}{$\mathbf{B P}^{3}$} \\
\hline & $\mathbf{P} 1^{4}$ & $\mathbf{P 2}^{5}$ & P1 & $\mathbf{P 2}$ & P1 & $\mathbf{P 2}$ \\
\hline Temperature $\left({ }^{\circ} \mathrm{C}\right)$ & $25.6 \pm 1.84$ & $24.4 \pm 1.95$ & $25.7 \pm 1.34$ & $24.3 \pm 1.65$ & $25.4 \pm 1.22$ & $24.5 \pm 1.04$ \\
\hline Dissolved oxygen / $\left(\mathrm{mg} \mathrm{L}^{-1}\right)$ & $7.32 \pm 0.68$ & $5.87 \pm 0.94$ & $7.76 \pm 0.75$ & $5.94 \pm 0.49$ & $7.97 \pm 0.35$ & $5.89 \pm 0.86$ \\
\hline Electric conductivity / $(\mu \mathrm{S})$ & $90 \pm 3.00$ & $103 \pm 2.00$ & $83 \pm 5.00$ & $94 \pm 4.00$ & $81 \pm 2.00$ & $99 \pm 6.00$ \\
\hline $\mathrm{pH}$ & $7.14 \pm 0.45$ & $8.01 \pm 0.74$ & $7.32 \pm 0.26$ & $8.34 \pm 0.35$ & $7.21 \pm 0.94$ & $8.03 \pm 0.37$ \\
\hline Turbidity / (NTU) ${ }^{6}$ & $20 \pm 4.00$ & $47 \pm 7.00$ & $26 \pm 2.00$ & $43 \pm 3.00$ & $29 \pm 5.00$ & $45 \pm 6.00$ \\
\hline Ammonia / $\left(\mathrm{mg} \mathrm{L}^{-1}\right)$ & $0.010 \pm 45^{-3}$ & $0.013 \pm 26^{-3}$ & $0.009 \pm 71^{-4}$ & $0.011 \pm 45^{-3}$ & $0.008 \pm 32^{-4}$ & $0.012 \pm 51^{-3}$ \\
\hline
\end{tabular}

(1) UA: urban area; (2) IM: Ilha do Massangano; (3) BP: Balneário de Pedrinhas; (4) P1: Period 1; (5) P2: Period 2;

(6) NTU: Nephelometric Turbidity Units. 
Table 3. Mean concentrations of heavy metals $\left(\mathrm{mgL}^{-1}\right)$, standard deviation and coefficient of variation of the different water collection sites of lower São Francisco River basin in Period 1.

\begin{tabular}{|c|c|c|c|c|c|c|c|c|c|c|c|}
\hline \multirow{2}{*}{ Metal } & \multirow{2}{*}{$\mathbf{M A V}^{1}$} & \multicolumn{3}{|c|}{ - } & \multicolumn{3}{|c|}{ - } & \multicolumn{3}{|c|}{--------(BP) ${ }^{7}--------$} & \multirow{2}{*}{$\begin{array}{l}\mathrm{CV}^{4} / \\
(\%)\end{array}$} \\
\hline & & Mean & Max.v. $^{2}$ & $\mathrm{SD}^{3}$ & Mean & Max.v. & SD & Mean & Max.v. & SD & \\
\hline Nickel* & 0.025 & $0.009^{\mathrm{ab}}$ & 0.020 & 0.005 & $0.011^{\mathrm{a}}$ & 0.022 & 0.005 & $0.007^{b}$ & 0.016 & 0.005 & 53.20 \\
\hline Cadmium & 0.001 & 0.006 & 0.015 & 0.004 & 0.007 & 0.016 & 0.003 & 0.008 & 0.029 & 0.009 & 89.58 \\
\hline Zinc & 0.180 & 0.019 & 0.033 & 0.008 & 0.017 & 0.029 & 0.006 & 0.016 & 0.064 & 0.016 & 64.20 \\
\hline Lead & 0.010 & 0.023 & 0.048 & 0.014 & 0.017 & 0.042 & 0.010 & 0.016 & 0.028 & 0.006 & 56.38 \\
\hline Iron & 0.300 & 0.285 & 0.872 & 0.294 & 0.337 & 0.917 & 0.277 & 0.370 & 1.098 & 0.279 & 88.76 \\
\hline Manganese* & 0.100 & $0.040^{\mathrm{b}}$ & 0.064 & 0.016 & $0.060^{\mathrm{a}}$ & 0.159 & 0.033 & $0.028^{\mathrm{c}}$ & 0.060 & 0.019 & 57.52 \\
\hline Chromium* & 0.050 & $0.076^{\mathrm{a}}$ & 0.089 & 0.020 & $0.036^{\mathrm{b}}$ & 0.075 & 0.023 & $0.032^{b}$ & 0.058 & 0.015 & 65.10 \\
\hline Copper & 0.009 & 0.004 & 0.014 & 0.003 & 0.004 & 0.009 & 0.002 & 0.005 & 0.011 & 0.002 & 64.20 \\
\hline
\end{tabular}

1- MAV: maximum allowed value (Conama); 2- Max. v.: maximum value; 3- SD: standard deviation; 4- CV: coeficiente of variation; 5- UA: urban area; 6- IM: Ilha do Massangano; 7- BP: Balneário de Pedrinhas. *Mean values followed by the same letter in the same row differ according to Tukey's test $(p<0.05)$.

Table 4. Mean concentrations of heavy metals $\left(\mathrm{mgL}^{-1}\right)$, standard deviation and coefficient of variation of the different water-collection sites in lower São Francisco River basin in Period 2.

\begin{tabular}{|c|c|c|c|c|c|c|c|c|c|c|c|}
\hline \multirow[b]{2}{*}{ Metal } & \multirow[b]{2}{*}{$\mathbf{M A V}^{1}$} & \multicolumn{3}{|c|}{ - } & \multicolumn{3}{|c|}{ - } & \multicolumn{3}{|c|}{ 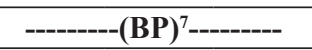 } & \multirow[b]{2}{*}{$\begin{array}{c}\mathrm{CV}^{4} / \\
(\%)\end{array}$} \\
\hline & & Mean & $\begin{array}{l}\text { Max. } \\
\text { v. }^{2}\end{array}$ & $\mathbf{S D}^{3}$ & Mean & $\begin{array}{c}\text { Max. } \\
\text { v. }\end{array}$ & SD & Mean & $\begin{array}{c}\text { Max. } \\
\text { v. }\end{array}$ & SD & \\
\hline Nicke & 0.025 & 0.028 & 0.054 & 0.018 & 0.041 & 0.096 & 0.032 & 0.028 & 0.053 & 0.021 & 76.94 \\
\hline Cadmium* & 0.001 & $0.012^{\mathrm{b}}$ & 0.021 & 0.007 & $0.020^{\mathrm{ab}}$ & 0.035 & 0.011 & $0.023^{\mathrm{a}}$ & 0.029 & 0.005 & 44.12 \\
\hline Zinc* & 0.180 & $0.008^{\mathrm{ab}}$ & 0.017 & 0.007 & $0.003^{b}$ & 0.008 & 0.003 & $0.013^{\mathrm{a}}$ & 0.019 & 0.004 & 60.73 \\
\hline Lead & 0.010 & 0.004 & 0.006 & 0.014 & 0.021 & 0.049 & 0.025 & 0.003 & 0.010 & 0.04 & 96.74 \\
\hline Iron & 0.300 & 0.596 & 0.821 & 0.130 & 1.129 & 2.090 & 0.671 & 0.749 & 1.162 & 0.351 & 53.80 \\
\hline Manganese* & 0.100 & $0.016^{\mathrm{a}}$ & 0.026 & 0.006 & $0.020^{\mathrm{a}}$ & 0.025 & 0.004 & $0.005^{\mathrm{b}}$ & 0.011 & 0.005 & 37.32 \\
\hline Chromium & 0.050 & 0.011 & 0.042 & 0.018 & 0.030 & 0.077 & 0.031 & 0.033 & 0.038 & 0.016 & 82.73 \\
\hline Copper & 0.009 & 0.018 & 0.596 & 0.013 & 0.006 & 0.017 & 0.007 & 0.013 & 0.020 & 0.007 & 75.44 \\
\hline
\end{tabular}

1- MAV: maximum allowed value (Conama); 2- Max. v.: maximum value; 3- SD: standard deviation; 4- CV: coeficiente of variation; 5- UA: urban area; 6- IM: Ilha do Massangano; 7- BP: Balneário de Pedrinhas. *Mean values followed by the same letter in the same row differ according to Tukey's test $(p<0.05)$.

Table 5. Mean correlation matrix of the analyzed elements of the water from lower São Francisco River basin.

\begin{tabular}{ccccccccc}
\hline & $\mathbf{N i}$ & $\mathbf{C d}$ & $\mathbf{Z n}$ & $\mathbf{P b}$ & $\mathbf{F e}$ & $\mathbf{M n}$ & $\mathbf{C r}$ & $\mathbf{C u}$ \\
\hline $\mathbf{N i}$ & $\mathbf{1}$ & & & & & & & \\
$\mathbf{C d}$ & -0.43 & $\mathbf{1}$ & & & & & \\
$\mathbf{Z n}$ & 0.41 & -0.12 & $\mathbf{1}$ & & & & \\
$\mathbf{P b}$ & -0.26 & $0.76^{* *}$ & 0.06 & $\mathbf{1}$ & & & \\
$\mathbf{F e}$ & $0.75^{* *}$ & -0.48 & 0.27 & $-0.53^{*}$ & $\mathbf{1}$ & & \\
$\mathbf{M n}$ & 0.07 & -0.08 & 0.15 & $-0.51^{*}$ & -0.17 & $\mathbf{1}$ & \\
$\mathbf{C r}$ & $0.61^{*}$ & -0.35 & 0.43 & $-0.53^{*}$ & $0.71^{* *}$ & $0.79^{* *}$ & $\mathbf{1}$ & \\
$\mathbf{C u}$ & -0.08 & 0.31 & 0.24 & 0.30 & -0.03 & 0.23 & 0.18 & $\mathbf{1}$ \\
\hline
\end{tabular}

Average values of the periods of collections, applying the Spearman's test. *significant at $5 \%$ of probability $(p<0.05)$. **significant at $1 \%$ of probability $(p<0.01)$.

Period 2, affecting the elevation of the metals Ni, Cd, Fe, $\mathrm{Mn}$ and $\mathrm{Cu}$ seen in Table 4.

The important volume of rainfall in the previous months and on the collection days of Period 2 should be considered a determining factor of the concentration of heavy metals present in lower São Francisco River basin observed in Table 4. The average precipitation values during the 30 days prior to the collections of Period 2 were approximately $187 \mathrm{~mm}$, and there was precipitation of
$3 \mathrm{~mm}$ in collection Period 1 (CPTEC, 2013), demonstrating patterns in the rainfall with large differences between the collection periods.

These rains during collection period 2 are usually concentrated in a short period, with maximum precipitation in the hydrological year. However, several anthropic factors may be involved, fostering increase in the average concentration of metals, like leaching of the chemical products utilized in the cultivation of fruits from the 
semi-arid region and disposal of chemicals used in the industry sector, whose production peak is during this period. Similar to the results

Chiba et al. (2011) to study the seasonality of trace elements in a sub-basin of São Carlos-SP, Southeast Brazil, observed the rise of elements $\mathrm{Zn}, \mathrm{Cd}, \mathrm{Fe}$ and $\mathrm{Mn}$, a fact occurred due to higher precipitation of rain during periods of collections and justified the accumulation of metals, because the areas of collections are located in complex industries.

Table 5 shows a negative, strong correlation between $\mathrm{Pb}$ and the other elements, which leads us to confirm the inexistence of heavy mineral residues, which have other metals in their structure. Good correlations between a few elements like $\mathrm{Fe}$ and $\mathrm{Cr}$ and nickel can also be observed, thus showing the mineralogical affinities with existing mineral assemblages in the river, where, according to Landrigan et al. (2007), opaque minerals (magnetite, ilmenite, hydrated oxides), hornblende, hypersthene, augite, and others can be found; these are easily degraded by the intense physical processes in the region. Almeida et al. (2011), reported that the coarser sediments of São Francisco River are characterized by being immature, subarkosic and by having a high content of unstable heavy minerals (1 to $8 \%$ ).

More or less significant correlations appear between Fe and trace elements: 0.75 (Fe-Ni) and 0.51 (Fe-Cr). Such values suggest that these metals were associated with clay minerals and stable-to-ultrastable primary minerals. More or less significant values, in turn, suggest strong associations with oxyhydroxides and Fe hydroxides.

Cr had its highest concentration in Period 1, reaching an average value of $0.076 \mathrm{mg} \mathrm{L}^{-1}$ in UA and exceeding the maximum allowed value established in Resolution no. $357 / 2005$ of CONAMA(Brasil, 2005), which is $0.050 \mathrm{mg} \mathrm{L}^{-1}$. The UA is located within the central perimeter that divides the two cities under study, which have an active industrial sector in leather processing. Muniz et al. (2004) conducted a study on seasonal silver basin in Montevideo (Uruguay), found mean levels of $0.0600 \mathrm{mg} \mathrm{L}^{-1}$ of $\mathrm{Cr}$ in water during periods of lower precipitation, a fact occurred due to a greater concentration of $\mathrm{Fe}$ and present high correlation 0.71 (Fe-Cr) between these elements (Table 5) which tends to have a larger oxidation-reduction power, resulting in greater availability of $\mathrm{Cr}$ in the oxidized form.

Excess $\mathrm{Cr}$ becomes toxic, as a result of its exposure through inhalation and ingestion, producing toxicity in the lungs and stomach, because it is absorbed through cellular membranes and then infiltrates the interior of the cells. Dermal exposure to chromic acid causes skin damage, allowing rapid absorption of hexavalent chromium ions and leading to a potential acute chromium intoxication. $\mathrm{Cr}$ (VI) is considered a powerful carcinogen (Callender, 2005).

Metals like $\mathrm{Pb}$, at concentrations above the maximum allowed, mainly $\mathrm{Pb}$ had its highest concentration in Period 1 , reaching an average value of $0.023,0.017$ and $0.016 \mathrm{mg} \mathrm{L}^{-1}$ in UA, IM and BP and exceeding the maximum allowed value established in Resolution no. 357/2005 of CONAMA
(Brasil, 2005), which is $0.010 \mathrm{mg} \mathrm{L}^{-1}$. Are considered neurotoxicants, capable of inducing neural dysfunctions or causing damage to the central or peripheral nervous system. Exposure to these elements triggers a wide range of clinical manifestations from motor dysfunction and behavioral changes to psychosis (Candura et al., 2000; Segura-Muñoz et al., 2003). Zinc can cause irritation and corrosion of the intestinal tract, and may also lead to renal necrosis or nephritis, in the most severe cases (Barceloux and Barceloux, 1999). The high levels of $\mathrm{Zn}$, $\mathrm{Mn}$ and $\mathrm{Pb}$ observed in the shallow water of the stream highlight the need for periodically monitoring this body of water, considering the toxic and bio accumulative effects of these metals.

Almeida et al. (2011), conducted a study on heavy metals and water quality in the river segment between San Francisco Três Marias and Pirapora - MG, found clearly the influence of metals on the health of coastal fishermen, who used the river water without any treatment for consumption.

The $\mathrm{Cu}$ concentrations recorded in the water, especially in collection period 2, may cause deleterious effects on human beings if measures for decontamination of the water are not taken and if there is chronic human exposure to this environment. $\mathrm{Cu}$ is another essential element that at high concentrations can produce toxicity to human beings. $\mathrm{Cu}$ in high concentrations above $35 \mathrm{mg}$ daily, can cause great biochemical changes in the body and affect the performance of the central nervous system (Saint-Laurent et al., 2010).

Normal concentrations of $\mathrm{Ni}$ were found in collection period 1 . However, they were high in all the collection sites from Period 2. In Table 4, we can observe maximum values reaching $0.096 \mathrm{mg} \mathrm{L}^{-1}$ in IM, which is well above the allowed, so preventive measures for decontamination of these sites should be taken.

The deleterious effects on public health regarding the elevated concentrations of $\mathrm{Ni}$ were caused mainly by inhalation through the respiratory tract and ingestion of contaminated water, containing ultrafine particles of nickel metal, at one dose. This can normally result in greater inflammatory response, probably because the extremely small size of the particle and the large corresponding surface area can change several mechanisms of the organism, e.g. inhibit phagocytosis, increase oxidative stress, and increase inflammation in the lung epithelium, allowing the ultrafine particles to diffuse more rapidly within the lung interstitium and increasing the risk of lung cancer (Plumlee and Ziegler, 2005).

The concentrations of Fe verified in the water, especially during collection period 2, showed high levels, in accordance with the legislation. According to Richter and Azevedo Neto (1991), in Brazil, it is common to find water with high iron contents, especially from old lands and alluvia.

According to Feitosa and Manuel Filho (1997) in the human body, iron acts in the formation of hemoglobin (pigment of the red blood cell that carries oxygen from the lungs to the tissues). Its deficiency can cause anemia and excess can increase the incidence of heart disease and 
diabetes. The evaluation of iron in groundwater for human consumption is because of its organoleptic properties. Delvin (1998) states that accumulation of iron in the liver, pancreas and heart can lead to cirrhosis and liver tumors, diabetes mellitus and heart failure, respectively. Also, Mahan (2000) states that excess iron can help generate excessive amounts of free radicals that attack cellular molecules, thereby increasing the number of potentially carcinogenic molecules within them.

Cadmium was above the MAV in all sites and collection periods, according to the national legislation. Exposure to this metal causes symptoms similar to food poisoning. Accumulation of this metal in man results in the itai-itai disease, which causes problems in calcium metabolism, followed by decalcification, rheumatism, neuralgia and cardiovascular problems (Train, 1979). High concentrations accumulated in organisms destroy the testicular tissue and red blood cells and can lead to mutagenic and teratogenic effects (Manaham, 1994). In Taubaté, SP (Brazil) a very high level of cadmium was found in 58 samples of human colostrum (Nascimento et al., 2005), and speciation of trace elements in breast milk has been the subject of research with increasing frequency and complexity (Michalke, 2006).

Recent studies have shown significant concern of doctors and scientists about the chronic and subclinical toxicity by metals in the environment, as reported by a review of Brazilian pediatricians that emphasizes the deleterious effects to the nervous system of children by lead and mercury (Mello-da-Silva and Fruchtengarten, 2005) and a study in Bangladesh, which suggests that there is association between mortality and ingestion of water containing manganese (Hafeman et al., 2007). However, all trace elements evaluated in this study are in total concentrations which makes it its absorption and their effects depend on the chemical form that is the elements, the characterization of determined trace elements, express the real state which is the from lower São Francisco River basin, in the Petrolina-PE and Juazeiro-BA.

\section{Conclusions}

Throughout the course of the sampled lower São Francisco River basin, Petrolina-PE and Juazeiro-BA section, there was regular presence of metals $\mathrm{Cd}, \mathrm{Cr}, \mathrm{Ni}$ and $\mathrm{Cu}$ with probable origin in urbanization and industrialization, these sources being broken down by similarity analysis. There was also systematic presence of $\mathrm{Fe}, \mathrm{Zn}$ and $\mathrm{Pb}$, probably from the soil.

It is thus concluded that the lower São Francisco River basin, Petrolina-PE and Juazeiro-BA section has been influenced by urbanization and industrialization, and awareness programs can be established to monitor and mitigate future problems.

\section{References}

ALMEIDA, D.F., MARTINS, A.H. and TUNDISI, J.G., 2011. Weight-of-evidence on environmental impact assessment of metal contaminated sediments in the São Francisco River (Três
Marias, Minas Gerais, Brazil): a case study. Brazilian Journal of Biology = Revista Brasileira de Biologia, vol. 71, no. 4, pp. 961-973. http://dx.doi.org/10.1590/S1519-69842011000500016.

BARCELOUX, D.G. and BARCELOUX, D., 1999. Zinc. Journal of Toxicology: Clinical Toxicology, vol. 37, no. 2, pp. 279-292. http://dx.doi.org/10.1081/CLT-100102426. PMid:10382562.

BOLLER, M., 1997. Tracking heavy metals reveals sustainability deficits of urban drainage systems. Water Science and Technology, vol. 35 , no. 9, pp. 77-87. http://dx.doi.org/10.1016/S02731223(97)00186-8.

BRASIL, Conselho Nacional do Meio Ambiente - CONAMA, 2004. Resolução $n^{\circ} 344$, de 25 de março de 2004. Estabelece as diretrizes gerais e os procedimentos mínimos para a avaliação do material a ser dragado em águas jurisdicionais brasileiras, e dá outras providências. Diário Oficial da República Federativa do Brasil, Brasília, DF, 7 maio.

BRASIL, Conselho Nacional do Meio Ambiente - CONAMA, 2005. Resolução $n^{\circ} 357$, de 17 de março de 2005. Dispõe sobre a classificação dos corpos de água e diretrizes ambientais para o seu enquadramento, bem como estabelece as condições e padrões de lançamento de efluentes, e dá outras providências. Diário Oficial da República Federativa do Brasil, Brasília, DF, 18 mar.

BURBURE, C., BUCHET, J.-P., LEROYER, A., NISSE, C., HAGUENOER, J.-M., MUTTI, A., SMERHOVSKÝ, Z., CIKRT, M., TRZCINKA-OCHOCKA, M., RAZNIEWSKA, G., JAKUBOWSKI, M. and BERNARD, A., 2006. Renal and neurologic effects of cadmium, lead, mercury, and arsenic in children: evidence of early effects and multiple interactions at environmental exposure levels. Environmental Health Perspectives, vol. 114, no. 4, pp. 584-590. http://dx.doi.org/10.1289/ehp.8202. PMid: 16581550

CACHADA, A.F.O., 2007. Geoquímica e qualidade ambiental de solos urbanos. Aveiro: Departamento de Geociências, Universidade de Aveiro, 155 p. PhD Thesis.

CALLENDER, E., 2005. Heavy metals in the environment: historical trends. In: B.S. LOLLAR, ed. Environmental geochemistry, treatise on geochemistry. Oxford: Elsevier-Pergamon, vol. 9, pp. 67-105.

CANDURA, S.M., BUTERA, R., GANDINI, C., LOCATELLI, C., TAGLIANI, M., FASOLA, D. and MANZO, L., 2000. Occupational poisoning with psychiatric manifestations. Giornale Italiano di Medicina del Lavoro Ed Ergonomia, vol. 22, no. 1, pp. 52-61. PMid:10771760.

CENTRO DE PREVISÃO DE TEMPO E ESTUDOS CLIMÁTICOS - CPTEC [viewed 10 December 2014], 2013. [online]. Cachoeira Paulista. Available from: http://enos.cptec.inpe.br

CHIBA, W.A.C., PASSERINI, M.D., BAIO, J.A.F., TORRES, J.C. and TUNDISI, J.C., 2011. Seasonal study of contamination by metal in water and sediment in a sub-basin in the Southeast of Brazil. Brazilian Journal of Biology = Revista Brasileira de Biologia, vol. 71, no. 4, pp. 833-843. http://dx.doi.org/10.1590/ S1519-69842011000500004.

COMPANHIA HIDRO ELÉTRICA DO SÃO FRANCISCO CHESF [viewed 10 December 2014], 2014. [online]. Recife. [Available from: http://www.chesf.gov.br/SistemaChesf/Pages/ SistemaGeracao/Sobradinho.aspx/

DELVIN, T.M., 1998. Manual de bioquímica com correlações clínicas. São Paulo: Edgard Blücher.

ERNST, W.H.O., 1996. Biovailability of heavy metals and decontamination of soils by plants. Applied Geochemistry, 
vol. 11, no. 1-2, pp. 163-167. http://dx.doi.org/10.1016/08832927(95)00040-2.

EVANS, L.J., 1989. Chemistry of metal retention by soils. Environmental Science \& Technology, vol. 23, no. 9, pp. 10471056. http://dx.doi.org/10.1021/es00067a001.

FEITOSA F. A. C. \& MANUEL FILHO, J. M., 1997. Hidrogeologia: conceitos e aplicações. Fortaleza: Companhia de Pesquisa de Recursos Minerais, LABHID-UFPE.

FILIZOLA, H.F., GOMES, M.A.F. and SOUZA, M.D., 2006. Manual de procedimentos de coleta de amostras em áreas agrícolas para análise da qualidade ambiental: solo, água e sedimentos. Jaguariúna: Embrapa Meio Ambiente. 169 p. il.

FLORENCE, T.M. and BATLEY, G.E., 1980. Chemical speciation in natural waters. Critical Reviews in Analytical Chemistry, vol. 9, no. 3, pp. 219-296.

HAFEMAN, D., FACTOR-LITVAK, P., CHENG, Z., VAN GEEN, A. and AHSAN, H., 2007. Association between manganese exposure through drinking water and infant mortality in Bangladesh. Environmental Health Perspectives, vol. 115, no. 7, pp. 1107-1112. http://dx.doi.org/10.1289/ehp.10051. PMid:17637930.

HAJDÚ, A. and LICSKÓ, I., 1999. Environmental pollution caused by a non-ferrous metal smelter. Water Science and Technology, vol. 39, no. 10-11, pp. 165-168. http://dx.doi.org/10.1016/S02731223(99)00269-3.

INSTITUTO BRASILEIRO DE GEOGRAFIA E ESTATÍSTICA - IBGE, 2013. Censo Demográfico 2013. Brasília.

LANDRIGAN, P.J., LUCCHINI, R.G., KOTELCHUCK, D. and GRANDJEAN, P., 2007. Principles for prevention of the toxic effects of metals. In: G.F. NORDBERG, B.A. FOWLER, M. NORDBERG and L.T. FRIBERG, eds. Handbook on the toxicology of metals. 3rd ed. New York: Academic Press, cap. 16, pp. 319-337.

MAHAN, B.M., 2000. Química: um curso universitário. São Paulo: Edgard Blücher. 654 p.

MANAHAM, S.E., 1994. Environmental chemistry. USA: Lewis. 811 p.

MELLO-DA-SILVA, C.A. and FRUCHTENGARTEN, L., 2005. Riscos químicos ambientais à saúde da criança. Jornal de Pediatria, vol. 81, no. 5, suppl., pp. 205-211. http://dx.doi.org/10.1590/ S0021-75572005000700011. PMid:16355265.

MICHALKE, B., 2006. Trace element speciation in human milk. Pure and Applied Chemistry, vol. 78, no. 1, pp. 79-90. http:// dx.doi.org/10.1351/pac200678010079.

MUNIZ, P., VENTURINI, N. and GÓMEZ-ERACHE, M., 2004. Spatial distribution of chromium and lead in sediments from coastal areas of the Río de la Plata estuary (Montevideo, Uruguay). Brazilian Journal of Biology $=$ Revista Brasileira de Biologia, vol. 64, no. 1, pp. 103-116. http://dx.doi.org/10.1590/ S1519-69842004000100012.
NASCIMENTO, L.F.C., IZÁRIO FILHO, H.J., PEREIRA, M.L. and BACCAN, N., 2005. Quantificação de cádmio em colostro de mães brasileiras: um estudo regional. Revista Brasileira de Saú de Materno Infantil, vol. 5, no. 2, pp. 193-198.

PAULSON, A.J., 1997. The transport and fate of $\mathrm{Fe}, \mathrm{Mn}, \mathrm{Cu}$, $\mathrm{Zn}, \mathrm{Cd}, \mathrm{Pb}$ and $\mathrm{SO} 4$ in a groundwater plume and in downstream surface waters in the Coeur d'Alene Mining District, Idaho, U.S.A. Applied Geochemistry, vol. 12, no. 4, pp. 447-464. http://dx.doi. org/10.1016/S0883-2927(97)00013-9.

PLUMLEE, G.S. and ZIEGLER, T.L., 2005. The medical geochemistry of dusts, soils and other earth materials. In: B.S. LOLLAR, ed. Environmental geochemistry, treatise on geochemistry. Oxford: Elsevier, vol. 9, pp. 263-310.

RICHTER, C.A. and AZEVEDO NETO, J.M.A., 1991. Tratamento de água, tecnologia atualizada. São Paulo: Edgard Blücher.

SAINT-LAURENT, D., HÄHNI, M., ST-LAURENT, J. and BARIL, F., 2010. Comparative assessment of soil contamination by lead and heavy metals in riparian and agricultural areas (Southern Québec, Canada). International Journal of Environmental Research and Public Health, vol. 7, no. 8, pp. 3100-3114. http://dx.doi. org/10.3390/ijerph7083100. PMid:20948950.

SANTOYO, E., SANTOYO-GUTIÉRREZ, S. and VERMA, S.P., 2000. Trace analysis of heavy metals in groundwater samples by ion chromatography with post-column reaction and ultravioletvisible detection. Journal of Chromatography: A, vol. 884, no. 1-2, pp. 229-241. http://dx.doi.org/10.1016/S0021-9673(00)00358-7. PMid:10917442.

SEGURA-MUÑOZ, S.I., TREVILATO, T.M.M., TAKAYANAGUI, A.M.M., HERING, S.E. and CUPO, P., 2003. Metales pesados en agua de bebedores de presión. Archivos Latinoamericanos de Nutricion, vol. 53, no. 1, pp. 59-64. PMid:12942873.

SELL, N.J., 1992. Industrial pollution control: issues and techiniques. 2nd ed. New York: Van Nostrand Reinhold.

SILVA, F.A.Z., 2010. ASSISTAT-7.5: programa de assistência técnica e estatística. Universidade Federal da Paraíba.

STUMM, W. and MORGAN, J.J., 1981. Aquatic chemistry. New York: Wiley-Interscience. 583 p.

STUMM, W., 1992. Chemistry of the solid-water interface. New York: Wiley-Interscience. $428 \mathrm{p}$.

TARLEY, C.R.T. and ARRUDA, M.A.Z., 2003. Adsorventes naturais: potencialidades e aplicações da esponja natural (Luffacylindrica) na remoção de chumbo em efluentes de laboratório. Reviews in Analgesia, vol. 4, pp. 25-31.

TRAIN, R.E., 1979. Quality criteria for water. Washington: EPA. 255 p.

VINK, R., BEHRENDT, H. and SALOMONS, W., 1999. Development of the heavy metal pollution trens in several European Rivers: an analysis of point and diffuse sources. Water Science and Technology, vol. 39, no. 12, pp. 215-223. http:// dx.doi.org/10.1016/S0273-1223(99)00338-8. 